\title{
Influence of Organizational Support Practices on Employees' Career Development in the Nigerian National Petroleum Corporation
}

\author{
Egbuta, Olive U. (PhD) \\ Department of Business Administration \& Marketing, Babcock University, Ilisan-Remo, Nigeria \\ Akinlabi, Babatunde Hamed (PhD) \\ Department of Business Administration \& Marketing, Babcock University, Ilisan-Remo, Nigeria
}

\begin{abstract}
The study investigated the influence of organizational support practices on employee career development in NNPC. Descriptive survey research design was adopted. Population of the research consisted of 9,024 top level, middle level and lower level management (Supervisors) staff of the NNPC who has spent more than 5years in the organization and have up to 5 years before retirement age of 60 years. Sample size of 1,960 was derived using Slovin formula and purposive sampling procedure. Structured and validated questionnaire with a six point modified Likert- Scale was administered with a $74.6 \%$ response rate (926) copies of the questionnaires came correctly and were used for the study. Data obtained from the questionnaire was analyzed quantitatively using descriptive and inferential statistics. Results revealed lack of Organizational support practices, no established career path for every employee and professional groups, organization Support practice with respect to supervisors in NNPC is not encouraging. The study concludes that organization Support practice has no significant influence on Employee Career Development in NNPC. It recommended that NNPC should adopt an integrated approach toward formulation and implementation of HRM practices. This will provide wholistic approach to the implementation of HRM in the Corporation and it's Strategic Business Units (SBUs).
\end{abstract}

Keywords: Corporations, Employees Career development, NNPC, Nigeria, Organization Support.

DOI: $10.7176 / \mathrm{EJBM} / 11-18-04$

Publication date:June $30^{\text {th }} 2019$

\section{Introduction}

The link between organizational support and employees' career development has received a lot of focus by studies. Several studies have investigated the impact of organizational support on employee career satisfaction, motivation and perception (Sharjeel, Saleem \&Amin.2013) analyses the supportive role of learning organization towards the individuals' careers in Pakistani. Barnett and Bradley (2007), while studying the relationship between organizational support for career development (OSCD) and employees' career satisfaction observed that OSCD, proactive personality and career management behaviour were all positively related to career satisfaction; and career management behaviour mediated the relationship between proactive personality and career satisfaction. However, due to recent changes in the technological, economic and business environments that have brought about a predominance of organizational restructuring and the concurrent fact that there is a challenge in attracting employees with the necessary skills, organizations have been forced to find attractive ways to convince employees that their organization is better than others in the provision of opportunities, challenges and rewards, and one way to meet this challenge is to support employees to develop their own careers and increase career satisfaction (Barnett $\&$ Bradley, 2007). A leader who has high supervisor support is one that creates the feeling to be detected, valued, and cared (Saleem \& Amin, 2013).

Researchers have attempted to specify the role of the line manager concerning career development (Atkinson, 2002; Crawshaw \& Gameb, 2015, Yarnall, 1998). Crawshaw and Gameb (2015) in their study found that Line Managers play critical roles in the organization's Career development systems in that employees viewed career management as a relational process in which their managers provide a care-giving service to support the individual employee in his career development efforts. The roles that managers play can be grouped into three main categories: promoting career development concepts to their staff, spending time with staff individually on career development matters, and taking actions to further their staff's development. Workplace support for self-development reflects an employee's perceptions regarding the degree to which his/her organization and supervisor are supportive of voluntary employee learning/development (Atkinson, 2002; Orvis \& Leffler, 2011,).

It is widely asserted that for career development to be effective in organizations, line managers need to support the future development of their staff and have the necessary skills to coach and counsel them as appropriate; and so it is unlikely that individual employees, however committed, can successfully manage their careers without any support from their manager (Yarnall, 1998). To continuously manage careers, organizations are to develop strategies that meet the needs of both the individual and the organization and provides explicit framework for 
attracting, developing and retaining employees in line with business objectives (Atkinson, 2002).

There has been increasing insecurity and violence that has characterize the Oil and Gas Industry, higher incidences of Crude oil theft and on-going controversies characterizing the Petroleum Sector in the country( Ikelegbu,2005; Ikoh \& Ukpong, 2013,\& Newsom, 2011). The NNPC Leadership visits the Aso Rock State House and National Assembly Complex in Abuja very frequently to answer for one matter or the other (Nwachukwu \& Eboh, 2015; Suleiman 2011). It can be inferred that so frequent has been the invitation to NNPC officials and the honorable minister of Petroleum Resources that one could wonder if these public officers have enough time left to attend to the jobs for which they were employed, in the first place let alone focus on the development of the careers of their employees .. It can be deduced that, as the leadership are pre-occupied with efforts to save their jobs from political interferences (Sayne, Gillies, \& Katsouris, 2015) little time is left to do the real work on employee support for career development. The focus of the leaders in this situation is to just do the work without thinking of human capital development and employee career development. This situation poses a real challenge to employees' career development and in particular and human capital development in general for the National Oil and gas Industry

The paper will investigate the role that organizational support play in employee career development in the Nigerian setting. In addition, the few studies that have been conducted have focused on developing economies (Atkinson, 2002; Crawshaw \& Gameb, 2015; Sharjeel, Saleem \& Amin, 2013; Yarnall, 1998) and hardly involved in the Oil and Gas Industry. Therefore, there was a need to investigate the influence of Organizational support practices on employee career development in NNPC.

\section{Theoretical Review}

Theories are formulated to explain, predict and help in understanding phenomenon and in many cases challenge and extend existing knowledge within the limits of the critical bounding assumptions (David, 2009; Odhong, Were, \& Omolo, 2014). According to the researcher, the link between organizational support practices and employee career development is based on the following theoretical strands discussed below:

\subsection{Theory of Work Adjustment}

The Theory of Work Adjustment (TWA) was originally developed by Dawis, England and Lofquist (1964) from the University of Minnesota. It has since seen many revisions and updates. It is also known as Person-Environment Correspondence Theory. The Theory of Work Adjustment (TWA) is a class of theory in Career development that is anchored on the individual difference and tradition of vocational behaviour (Eggerth, 2008; Dawis, 2002, 2005). TWA view career choice and development as continual processes of adjustment and accommodation in which the more closely individuals' capabilities (knowledge, skills, attitudes, experience, and behaviours, etc.) relate with the requirements of the position or the organisation, the more likely it is that they will perform the job well and be perceived as satisfactory by the employer. Correspondingly, the more closely the reinforcers (rewards) of the position or organisation tally to the values that a person seeks to satisfy through their work, the more likely it is that such a person will perceive the job as satisfying. The Theory listed six key values that individuals seek to satisfy in the work place or any career they engage in: Achievement, Comfort, Status, Altruism, Safety, and Autonomy. In this reasoning, individuals would consider the degree of their satisfaction in consideration of how far each of these values are achieved at any particular time or on continuous basis.

This theory goes on to explain that the degrees of satisfaction and satisfactoriness are predictors of the probability that someone will stay in a job, be successful at it and receive advancement. TWA acknowledges that for various reasons, the relationship between the person and environment may not be perfect either because the individual chose the wrong career or the employer chose the wrong candidate. The person may have acquire new skills and may have outgrown the current role and desires a change; their personal priorities may change because of other private commitments; the nature of the job or the nature of the rewards an employer is able to offer may also change. In all these, the ability of the individual or the environment to exercise flexibility will determine the extent to which they can tolerate any lack of correspondence between abilities and requirements and/or values and reinforces. Flexibility will vary from individual to individual and from environment to environment but usually driven by internal factors, such as personality or organizational culture, as will external factors, such as the availability of alternative opportunities. When the lack of correspondence is so great that flexibility is no longer viable, some form of adjustment often takes place (Dawis, 2005).

TWA holds that individuals or environments will keep trying to adjust before giving up. When no further adjustment is possible, something more dramatic happens - the person leaves the job or they are fired. Career choice and development is consequently conceptualized as a continual process or cycles of work adjustment initiated by dis-satisfaction and dis-satisfactoriness. The TWA propositions are applicable in cross cultural settings like Nigeria where alternative jobs are not easy to come by and individuals and the organizations are engaged in gradual and consistent adjustments on continuous basis. This is a theory in Career development which views career choice as continual processes of adjustment and accommodation in line with the environmental considerations. 
This theory is appropriate in a developing nation like Nigeria where jobs opportunities are drying up and individuals are very happy to remain in a job that pays their salaries regularly; in such situations, even where the conditions are not right, the employees continue to adjust in reaction to the environmental realities.

\subsection{Organizational Support Theory (OST)}

Organizational Support Theory, holds that the formation of Perceived Organizational Support (POS) is encouraged by employees' inclination to assign the organization humanlike characteristics (Rhoades \& Eisenberger, 2002; Shore \& Shore, 1995) in which actions taken by agents of the organization are often regarded as indications of the organization's intent, rather than being credited solely to agents' personal motives. Accordingly, this personification of the organization is supported by the organization's legal, moral, and financial responsibility for the actions of its agents; by organizational policies, norms, and culture that provide continuity and prescribe role behaviours; and by the power the organization's agents exert over individual employees (Levinson, 1965). Based on these personifications of the organization, employees view favourable or unfavourable treatment received from the organization as an indication of the extent to which the organization values their contributions and cares about their well-being.

According to Rhoades and Eisenberger (2002); three major work-experience antecedents of POS: organizational rewards and working conditions support received from supervisors, and procedural justice. Considering these antecedents, in turn, research has identified a variety of rewards and favourable working conditions that are positively related to POS, such as developmental experiences allowing employees to expand their skills (Wayne, Shore, \& Liden, 1997), autonomy in the manner in which jobs are carried out (Eisenberger, Rhoades \& Cameron, 1999), and visibility to and recognition from upper-level management (Wayne, Shore, Bommer \& Tetrick, 2002). Another major antecedent of POS, perceived supervisor support, refers to employees' beliefs that their supervisors care about them and value their contributions (Akgunduz, Alkan \& Gok, 2018, Wu \& Liu, 2014 ;). Supervisors act as representatives of the organization and are frequently charged with evaluating employees and communicating the organization's goals and values to employees. As such, employees have been found to identify treatment by their supervisor as indicative of organizational support (Eisenberger et al., 2002). Consequently, employees view Perceived Supervisor Support (PSS) as Perceived organizational support (POS) (Eisenberger, et al., 2002b).

The third major antecedent, is procedural justice, involves the fairness of formal organizational policies and procedures for distributing resources (Greenberg, 1990). Shore and Shore (1995) argued that perceptions of procedural justice would result from specific decisions made by the organization, such as pay raises and promotions. Shore and Shore (1995) in further explanation suggested that employees' repeated exposure to fair procedures would accrue positively to POS. A related concept, involving unfair treatment, is organizational politics. Perceived attempts to influence others in ways that promote self-interest, often at the expense of the rewards for individual merit or the betterment of the organization, are negatively related to Perceived Organizational Support (Demir, 2015; Eder \& Eisenberger, 2008; Randall, Cropanzano, Bormann, \& Birjulin, 1999; \& Cropanzano, Howes, Grandy, \& Toth, 1997).

\subsection{Empirical Review \\ 2.2.1 Employees Career Development \\ 2.2.2 Career Development}

Studies on Careers have identified a number of factors that affects Career decisions in the work place and a number of empirical studies have investigated this. A study carried out by Schein (1990) emphasizes that certain behavioural patterns, values and attitudes that determine and govern the person's career are developed in his or her early years. These behavioural patterns consist of the combination of needs and instincts, and help the person to choose between a few related careers (Bayram, 2008). These sets of values consisted of needs and instincts manage, balance and complete a person's work experiences. Therefore, it makes it easier for a person to make a choice about his or her career. Career development programs are intended to develop employees, and prepare them for future jobs and positions, with higher responsibilities, and it is expected to help them in developing their career, which would concomitantly result in the satisfaction of those employees. Extant researchers identified organizational supports as key dimension of Human Resource Management whose integration can improve employees' career development (Rasool, Kiyani, Aslam \& Akran, 2012).

Rasool, et al. (2012) observed that career salience is focused on the comparative value of work and career within an individual total life. This is important because individual chose a profession for a purpose to meet a personal social needs, but the exigent of making a particular profession a lifelong career does differ from one individual to the other. The study established that there is a significant relationship between organizational culture and employee career salience. Briscoe, Hall and Demuth (2006) carried out three studies that were reported as one study of Protean and Boundaryless Career: An Empirical Exploration; they set out to develop new scales to measure Protean and Boundaryless career attitudes. The study found that mobility preference did not necessarily 
correlate with either the Protean Career or the Boundaryless Mind-set. It established that being Protean career or the Boundaryless in terms of career attitude is not synonymous with job mobility preference. The study also showed that proactive personality correlated with self-directed career management, value-driven, Boundaryless mind-set and mobility preferences. The study seems to validate the idea that those with Protean and Boundaryless Career attitude are assertive in their posture, and do not wait for events to control them.

Agba, Nkpoyen and Ushie (2010) in a study of Career Development and Employee Commitment in Industrial Organization in Calabar, Nigeria, asserts that due to improved living standard most workers are no longer satisfied to have just a job rather people want a career that expresses their interest, personality, abilities and that harmonizes with their total life situation. The researchers noted that most organizations have failed to satisfy this need as the tools and experiences the organizations provide do not support the employees to develop in their career. The study found a significant relationship between career advancement and employee commitment, It also revealed a significant relationship between career opportunity and employee commitment indicating that people want many other things in their jobs and not only financial benefits. They hold that employees want organizations management to show an interest in their Career development and progression; and where this exists, employee's commitment increases.

Shujaat, Sena, Aftab and Ahmed (2013), noted that for Career Development actions to be successful, employees, managers and organization must be involved in every step of it they asserts that employees have to carefully consider and decide what they really want from their career, what their objective is, managers will then ascertain their knowledge, skills and abilities to enable them to be trained accordingly, support the employee in recognizing their short term and long term goals. The responsibility of the Organizations is to provide them time, benefits and funds according to their requirement, create the enabling environment for supporting them for their goals and be willing to use new knowledge, skills and abilities of each employee to achieve organizational goals. Shujaat et al (2013) found a significant positive relationship between Career Development and Employee job satisfaction in banking sector. This shows that employees were more satisfied when Career Development opportunity activities are offered at their organizations. It further determined that the corporate world has become more competitive hence employees have become more conscious of the need to develop their Career in order to remain and improve their employability.

In an empirical study of three selected industries in Nigeria, Fapohunda (2012) found that many employees in the Nigeria are casual workers... The researcher, found a high incidence of casualization, job insecurity and that labour standards are being compromised because of the difficult economic environment especially in the Nigerian Oil and Gas Industry. The increase of casualization was also common in the Banking Industry and even in Central Bank of Nigeria. The study found that casual workers are not full career employees; casual workers are not unionized, receive lower wages and few benefits, frequently paid off and have no job security. This existing situation has affected the level of commitment which employees have for their employers (Fapohunda, 2012). In conclusion the researchers recommended that HRM and HRD Managers should create a framework that encourages employees towards professional dedication. This way HRM would be contributing to maintain and retain valuable workers for the organization. The study by Wen\& Saidin,,2018 among Administrative Staff of newly established University in China and another study by Meiske (2018) amomg although carried out in different geographical areas all found that perceived organizational support is viewed by employees as a high. The two studies found that when employees perceive that their organization as being supportive of their career and well-being, they would exhibit high job satisfaction and this results in higher citizen behaviour.

Danesi (2015) in her work noted that like other parts of the world, Nigeria had and continues to experience serious economic and financial meltdown which has led to wide spread unemployment. The changes in the economic situation have grossly affected employment relationships resulting in high incidences of Job insecurity, job losses. This situation has fostered little or no attachment between workers and the firms they work with. Those in employment are no longer sure of their tenure; even workers in public sector who in the past enjoyed job security and the benefits that go with it were being laid off. This is the situation in Nigeria including those in the Oil and Gas industry where there are high incidences of labour casualization. This being the case, many employees are adjusting to the situation in order to hold their economic means of livelihood and this is changing nature of work in Nigeria(Denesi,2015). In evaluating the opinions with regard to what Career Development can do, the results showed that, attitudes of the general management, the perceived effect on Supervisory responsibilities, and attitudes regarding the administration of Career development programs, were positive.

These foregoing studies showed that career development decision, will influence how employee feels at work, and their subsequent perceptions of justice. In this regard, managers in organizations need to be aware, of the interpretations that employees may make of the messages they send to organization members by their decisions, which are related to Career Development. The study by Bish, Bradley, \& Sargent (2004) is different from the present work, but it is being cited as it demonstrates that, decisions regarding organizational Career Development activities, are important to employees, and will influence how those employees regard the organization. In order words, when organizations show interest in the career development of their workers (employees) and put policies 
and framework in place for it to happen, the employees (workers) on their side regard this as an evident of the worth the organization places on them and their future wellbeing.

The study by Kaya and Ceylan (2014), noted that line managers and employers have realized that they cannot obtain a good performance from their employees in a situation where both employee career management and organizational career management practices are absent. They asserts that the pre-requisites for making a difference in a competitive environment lies in investing in people and performing both individual and organizational career processes. Kaya and Ceylan (2014) revealed that career development programs are very essential for employee as well as the organization. The study used career development programs and organizational commitment as independent variables while job satisfaction was used as the dependent variable. The study found; that because of the changes in the business environment, the needs and demands of employees are also changing and so the factors that motivate them are also changing...

Organization's workforces are demanding for more than financial benefits and satisfaction; they are now seeking for moral, emotional and psychological satisfaction. In this situation, the research found that organization's that have embedded effective and efficient career management systems; promotions, transfer (Job Rotation) opportunities, education and development opportunities in their condition of service would attract and retain high potential employees. Another salient finding from the study is that career development programs in an organization do not affect the level of employee Job satisfaction, but the implementation of career development will however make the employees to become more aware of themselves, their direction and where they want to be or go. Another study by Shah, Mallah, and Shabana (2015), also found a positive and significant relationship between HRM practices and employee retention.

\subsubsection{Organizational Support Practices}

Saleem and Amin (2013) considered the difference in the significance and commitment attached to the individuals' career development and its integration into the Human Resource Processes and procedures by organizations following different types of management styles. The study found that supportive role of learning organization had a high significance towards the individuals' careers development. The organizational support for career development and supervisory support are independent variables and employees' performance is dependent variable. Saeed, Lodhi, Abbas, Ishfaque, Dustgeer and Ahmed (2013) in their study to examine the impact of organizational role in career development of an employee revealed that there is a positive and significant relationship between the organizational role and employee Career development.

In a similar study Barnett and Bradley (2007), had earlier examined the relationship between organisational support for career development (OSCD) and employees' career satisfaction. Based on an extended model of social cognitive career theory (SCCT) and an integrative model of proactive behaviours, the study proposed that career management behaviours would mediate the relationship between OSCD and career satisfaction, and between proactive personality and career satisfaction. They found that OSCD, proactive personality and career management behaviours were all positively related to career satisfaction and career management behaviours mediated the relationship between proactive personality and career satisfaction. The results suggest that there are benefits for organisations and individuals investing in career development. First, from an organisational perspective, investing in OSCD may enhance employees' career satisfaction. Second, employees may enhance their own career satisfaction by participating in career management behaviours.

Similarly, Kang, Gatling and Kim (2014) carried out a study on the Impact of Supervisory support on Organizational commitment, career satisfaction and turnover intention for hospitality frontline employees; the result showed that Supervisory support had a positive effect both on the employee's organizational commitment and their career satisfaction.

Demir (2015) in his study on: The effect Organizational Justice and Perceived Organizational Support on Organizational Citizenship Behaviour, noted that although many researches do not include the individual sense of belonging which is a vital component of organizational life yet he observed that organizational identification is one of the most crucial factors holding employees together and keeping them committed to the organization. A number of studies have demonstrated that organizational identification is positively related to organizational citizenship behavior. While others have suggested that organizational identification also might play an important role in social exchange processes. In his own particular study, whose main objective was to investigate how organizational identification on the part of employees facilitates and influences the employees' perceptions of organizational justice and organizational support on organizational citizenship behaviors? His study was however domiciled on the Turkish pre-school teachers. His findings showed that organizational identification, and perceived organizational justice and organizational support are related to organizational citizen behaviour and is positively related to Organizational performance. In conclusion; the results of the study demonstrate that where and when teachers identify with the school, it plays a significant role in promoting organizational citizenship behaviors. This study's findings also established that teachers' organizational citizenship behavior improves school effectiveness. Consequently, the study recommends that school Principals should understand and make use of these dispositions and attitudes in improving the performance of their teachers and therefore their teachings. 
In yet another study (Gilbert, Djebarni \& Thomas, 2015) found that there is lack of significant impact of interpersonal trust in the Nigeria Oil Industry and this did affect the degree of change implementation. The explanation for the lack of significant influence of interpersonal trust could be according to the researchers that NNPC value for interpersonal relationship enhancement is very low. This means that the organizational practices may not be consistent with critical behaviour for influencing positive interpersonal trust.

Furthermore, Gilbert (2014) in his empirical study of the NNPC, also found that there is lack of Organizational trust. He established that lack of organizational trust reduces cooperation and communication among organizational members thereby impeding individual readiness for change and organizational change implementation. He noted in his study that the daily operations of the NNPC centered in the office of the GMD, and that the powers/authorities of other senior executives' officers under the GMD are often limited with the influence of political leaders outside the corporation. This situation has over the years affected the different aspects of the organization especially the Human resources management practices.

The empirical review reveals the following hypothesis:

$\mathrm{H}_{0}$ : Organizational support practices do not significantly influence employees' career development.

\section{Methodology}

This study adopted descriptive survey research design of correlational type using questionnaire and structured interview. This design provides the opportunity of describing existing conditions through the collection of primary data. The research design is appropriate for this study because it allowed the data generated to be analyzed quantitatively and to draw inferences about relationships among the variables. The research design adopted would help to establish the influence of Organizational support practices on employees' career development in NNPC. The dependent variable was considered as a continuous variable and thus regression analysis was adopted as recommended by Field (2009). Univariate analysis was used to perform regression on the influence of the independent variable on the dependent variable. In particular, organizational support practices was regressed on employees' career development as shown below.

\subsection{Employees' career development $=\beta_{0}+\beta_{1}$ organizational support practices $+\varepsilon_{i}$}

The population of this study comprised 9,024 top level, middle level and lower level management (Supervisors) staff of the NNPC who has spent more than 5years in the organization and have up to 5 years before retirement age of 60 years. The NNPC is made up of Twelve Subsidiary companies and two partly owned subsidiaries and some associated companies manage the Upstream, Mid-stream and Downstream activities of the NNPC (NNPC, 2014). Due to this wide geographical spread, limited time factor as well as the financial constraints on the study, the researcher purposefully chose Strategic Business Units (SBUs) in two cities to focus the study on. The cities are Abuja (Corporate Headquarters \& PPMC Headquarters), and Lagos (NAPIMS). The operations of the SBUs chosen cut across the main sectors of the Oil and Gas Business: Upstream, Downstream and Commercial and Investment Sectors. Thus, purposive sampling and proportional sampling techniques was adopted in selecting the 944 participants in the SBUs and locations. These were adopted in order to ensure that the different stratum of the management in each location is represented.

Primary data was utilized in this study. Primary data was collected using a semi-structured questionnaire administered to thirteen NNPC Executives and Directors. Close-ended questions constructed a 6-point Likert scale (1-strongly disagree and 6-strongly agree) provided structured responses that facilitated quantitative analysis, testing of hypothesis, and drawing conclusion. However, open-ended questions provided additional information that may not have been captured by the close-ended questions.

In order to explore the factors that can affect employee career development, a pilot study was undertaken. The pilot study was carried out at the NNPC/PPMC Mosimi Area Office in Ogun State which is another section of the organization that is not part of the study population. A total of 100 questionnaires were distributed and 94 were returned.

Face and content validity of the questionnaire items for the two research variables were verified. The drafted copies of the questionnaire were given to Specialists in Human Resources and Strategic Management to look at the structure and construction of questions in order to ensure accuracy and that it aligns with the different dimensions of the study. Furthermore, factor analysis confirmed that the study variables had construct validity as recommended by Kerlinger and Lee (2000). The reliability of the instrument was established through Cronbach's alpha coefficient for each variable. Cronbach's alpha values for the study variables was established at 0.74 and 0.73 for organizational support practices and employee career development which lie within the threshold of at least 0.7 recommended by Bryman and Bell (2011) and thus confirmed the reliability of the items utilized in the study instrument. The researcher administered the questionnaire through hand-delivery and collected the completed copies of questionnaire the next day or two as the case maybe. This approach facilitated the retrieval of the questionnaires from the respondents.

Quantitative data was analyzed by use of descriptive statistical tools which helped the researcher to describe 
the data and determine the extent used. This included frequency distributions, tables, percentages, mean, and standard deviation. Data was analyzed using SPSS and Microsoft excel. Tables were used to summarize responses for further analysis and facilitate comparison. Simple regression model was used to test the hypothesis formulated.

\section{Results and Discussion}

The researcher administered 1235 copies of the questionnaire, out of which 926 were filled-in and returned translating to $74.9 \%$ response rate. The remaining 309 copies of the questionnaire could not be retrieved because the participants did not continue with the study while others were not properly filled or mutilated. This response rate is considered sufficient for making inferences and drawing conclusions from the research data.

\subsection{Descriptive Statistics}

The study sought to determine the extent to which respondents agreed with the following statements assessing the level of organizational support practices in NNPC. The sample measures that were pertinent to the objectives of this study were frequency, percentages, mean and standard deviation were used as a basis summarizing, describing and comparing research variables numerically as well as revealing pattern of sample data set.

Table 1: Descriptive Statistics for Employees' Career Development

\begin{tabular}{|c|c|c|c|c|c|c|c|c|}
\hline Career and Development & 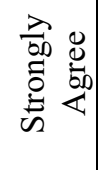 & 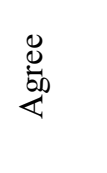 & 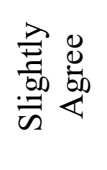 & 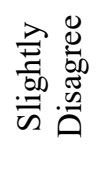 & 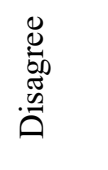 & 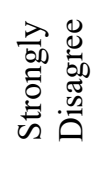 & 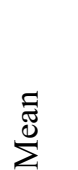 & 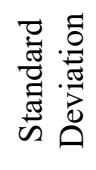 \\
\hline $\begin{array}{l}\text { NNPC has an established career path the } \\
\text { corporation use for every employee \& } \\
\text { professional groups }\end{array}$ & $\begin{array}{c}47 \\
(5.1)\end{array}$ & $\begin{array}{c}83 \\
(9.0)\end{array}$ & $\begin{array}{c}112 \\
(12.1)\end{array}$ & $\begin{array}{c}273 \\
(29.5)\end{array}$ & $\begin{array}{c}194 \\
(21.0)\end{array}$ & $\begin{array}{c}162 \\
(17.5)\end{array}$ & 3.01 & 1.510 \\
\hline $\begin{array}{l}\text { Employees in the corporation understand } \\
\text { what to do to at any time to make progress } \\
\text { in their career. }\end{array}$ & $\begin{array}{c}56 \\
(6.0)\end{array}$ & $\begin{array}{c}155 \\
(16.7)\end{array}$ & $\begin{array}{c}62 \\
(6.7)\end{array}$ & $\begin{array}{c}173 \\
(18.7)\end{array}$ & $\begin{array}{c}195 \\
(21.1)\end{array}$ & $\begin{array}{c}260 \\
(28.1)\end{array}$ & 3.51 & 1.941 \\
\hline $\begin{array}{l}\text { Training and development opportunities are } \\
\text { explicitly linked to the strategic direction of } \\
\text { NNPC }\end{array}$ & $\begin{array}{l}23 \\
(2.5)\end{array}$ & $\begin{array}{l}47 \\
(5.1)\end{array}$ & $\begin{array}{l}200 \\
(21.6)\end{array}$ & $\begin{array}{l}203 \\
(21.9)\end{array}$ & $\begin{array}{l}199 \\
(21.5)\end{array}$ & $\begin{array}{l}238 \\
(25.7)\end{array}$ & 3.50 & 1.637 \\
\hline $\begin{array}{l}\text { Employees in NNPC receive formal Career } \\
\text { advice from their Supervisors and } \\
\text { Managers. }\end{array}$ & $\begin{array}{l}39 \\
(4.2)\end{array}$ & $\begin{array}{l}69 \\
(7.5)\end{array}$ & $\begin{array}{l}149 \\
(16.1)\end{array}$ & $\begin{array}{l}215 \\
(23.2)\end{array}$ & $\begin{array}{l}214 \\
(23.1)\end{array}$ & $\begin{array}{l}224 \\
(24.2)\end{array}$ & 3.52 & 1.352 \\
\hline $\begin{array}{l}\text { There is a Formal Mentoring and Career } \\
\text { Development workshops, }\end{array}$ & $\begin{array}{l}29 \\
(3.1)\end{array}$ & $\begin{array}{l}100 \\
(10.8)\end{array}$ & $\begin{array}{l}180 \\
(19.4)\end{array}$ & $\begin{array}{l}182 \\
(19.7)\end{array}$ & $\begin{array}{l}215 \\
(23.2)\end{array}$ & $\begin{array}{l}202 \\
(21.8)\end{array}$ & 3.26 & 1.425 \\
\hline $\begin{array}{l}\text { Employees in the corporation know what the } \\
\text { key skills are that Corporation needs in the } \\
\text { next five years to achieve its objectives. }\end{array}$ & $\begin{array}{l}18 \\
(1.9)\end{array}$ & $\begin{array}{l}159 \\
(17.2)\end{array}$ & $\begin{array}{l}117 \\
(12.6)\end{array}$ & $\begin{array}{l}167 \\
(18.0)\end{array}$ & $\begin{array}{l}199 \\
(21.5)\end{array}$ & $\begin{array}{l}245 \\
(26.5)\end{array}$ & 3.21 & 1.698 \\
\hline $\begin{array}{l}\text { The business strategy of the Corporation is } \\
\text { consistently communicated to all levels of } \\
\text { employees though the management chain, } \\
\text { through special communications and } \\
\text { through training and development activities }\end{array}$ & $\begin{array}{l}27 \\
(2.9)\end{array}$ & $\begin{array}{l}177 \\
(19.1)\end{array}$ & $\begin{array}{l}88 \\
(9.5)\end{array}$ & $\begin{array}{l}185 \\
(20.0)\end{array}$ & $\begin{array}{l}193 \\
(20.8)\end{array}$ & $\begin{array}{l}234 \\
(25.3)\end{array}$ & 3.33 & 1.690 \\
\hline $\begin{array}{l}\text { Employees are actively encouraged to share } \\
\text { their knowledge with colleagues, not just } \\
\text { subordinates, by coaching, mentoring and } \\
\text { formal training within their work group and } \\
\text { cross-functionally }\end{array}$ & $\begin{array}{l}23 \\
(2.5)\end{array}$ & $\begin{array}{l}96 \\
(10.4)\end{array}$ & $\begin{array}{l}35 \\
(3.8)\end{array}$ & $\begin{array}{l}145 \\
(15.7)\end{array}$ & $\begin{array}{l}497 \\
(53.7)\end{array}$ & $\begin{array}{l}153 \\
(16.5)\end{array}$ & 2.38 & 1.996 \\
\hline $\begin{array}{l}\text { There is ample Career advancement } \\
\text { opportunities that is open to all relevant } \\
\text { employees in the corporation }\end{array}$ & $\begin{array}{l}39 \\
(4.2)\end{array}$ & $\begin{array}{l}191 \\
(20.6)\end{array}$ & $\begin{array}{l}53 \\
(5.7)\end{array}$ & $\begin{array}{l}220 \\
(23.8)\end{array}$ & $\begin{array}{l}186 \\
(20.1)\end{array}$ & $\begin{array}{l}219 \\
(23.7)\end{array}$ & 3.51 & 1.341 \\
\hline $\begin{array}{l}\text { There is visibility to Senior management in } \\
\text { the organization on matters of Career } \\
\text { Development }\end{array}$ & $\begin{array}{l}27 \\
(2.9)\end{array}$ & $\begin{array}{l}167 \\
(18.0)\end{array}$ & $\begin{array}{l}72 \\
(7.8)\end{array}$ & $\begin{array}{l}211 \\
(22.8)\end{array}$ & $\begin{array}{l}216 \\
(23.3)\end{array}$ & $\begin{array}{l}210 \\
(22.7)\end{array}$ & 3.37 & 1.373 \\
\hline
\end{tabular}

Source: Researcher's Field Survey Result, 2018

Table 1 presents respondents opinion on Career Development measuring scale. The results of descriptive analysis showed that NNPC does not have established Career path for employees and professional groups as 
reported by $629(67.9 \%)$. The majority $(67.8 \%)$ of respondents indicates that employees in NNPC do not understand what to do at any time to make progress in their career (strongly disagreed, disagreed and slightly disagreed combined). Also, the Table revealed that in the Corporation, majority of the respondents (69.1\%) disagreed that training and development opportunities are explicitly linked to the strategic direction of NNPC.

Furthermore, the result reveals that employees in NNPC do not receive formal Career advice from their supervisors and managers. A total of $70.5 \%$ of the respondents confirm this. 599 or $64.7 \%$ of the respondents declined that there is a Formal Mentoring and Career Development workshops in the Corporation, (65.9\%) disagreed that employees in the corporation know what the key skills are that Corporation needs in the next five years to achieve its objectives, $(61.2 \%)$ are of the view that the business strategy of the Corporation is not consistently communicated to all levels of employees through the management chain, through special communications and through training and development activities, $(85.9 \%)$ reflect that employees are not actively encouraged to share their knowledge with colleagues, not just subordinates, by coaching, mentoring and formal training within their work group and cross-functionally, $(67.5 \%)$ disagreed that there is ample Career advancement opportunities that is open to all relevant employees in the corporation and (68.8\%) disagreed that there is visibility to Senior management in the organization on matters of career development.

It is evident from the results of descriptive analysis about career development that there is no established career path for every employee and professional groups in NNPC; and training and development opportunities are not explicitly linked to the strategic direction of NNPC. As a result, employees do not really know the key skills that Corporation needs to achieve its objectives. In addition, employees in NNPC do not receive formal Career advice from their Supervisors and Managers. Table 2 presents the effects of Organizational Support practices on career development in NNPC.

Table 2: Descriptive Statistics for Organizational Support

\begin{tabular}{|c|c|c|c|c|c|c|c|c|}
\hline Organizational Support Practices & $\begin{array}{l}\text { VS } \\
(\%)\end{array}$ & $\begin{array}{c}\mathbf{S} \\
(\%)\end{array}$ & $\begin{array}{c}\text { SS } \\
(\%)\end{array}$ & $\begin{array}{c}\text { SD } \\
(\%)\end{array}$ & $\begin{array}{c}\text { D } \\
(\%)\end{array}$ & $\begin{array}{l}\text { VD } \\
(\%)\end{array}$ & $\bar{X}$ & SD \\
\hline $\begin{array}{l}\text { Overall, how satisfied are you with } \\
\text { the level of support you are receiving } \\
\text { as it affects your Career } \\
\text { Development.? }\end{array}$ & $\begin{array}{c}49 \\
(5.3)\end{array}$ & $\begin{array}{c}143 \\
(15.4)\end{array}$ & $\begin{array}{c}429 \\
(46.3)\end{array}$ & $\begin{array}{c}128 \\
(13.8)\end{array}$ & $\begin{array}{c}142 \\
(15.3)\end{array}$ & $\begin{array}{c}25 \\
(2.7)\end{array}$ & 3.6649 & 1.30140 \\
\hline $\begin{array}{l}\text { Your Supervisor: } \\
-\quad \text { How satisfied are you with } \\
\text { how fairly your Supervisor treats } \\
\text { you? }\end{array}$ & $\begin{array}{c}69 \\
(7.5)\end{array}$ & $\begin{array}{c}186 \\
(20.1)\end{array}$ & $\begin{array}{c}433 \\
(46.8)\end{array}$ & $\begin{array}{c}102 \\
(11.0)\end{array}$ & $\begin{array}{c}88 \\
(9.5)\end{array}$ & $\begin{array}{c}32 \\
(3.5)\end{array}$ & 3.9202 & 1.35381 \\
\hline $\begin{array}{l}\text { - How satisfied are you with } \\
\text { your Supervisor's position when you } \\
\text { have a problem with a co-worker in } \\
\text { another department? }\end{array}$ & $\begin{array}{c}70 \\
(7.6)\end{array}$ & $\begin{array}{c}193 \\
(20.8)\end{array}$ & $\begin{array}{c}336 \\
(36.3)\end{array}$ & $\begin{array}{c}139 \\
(15.0)\end{array}$ & $\begin{array}{c}122 \\
(13.2)\end{array}$ & $\begin{array}{c}54 \\
(5.8)\end{array}$ & 3.9074 & 1.39524 \\
\hline $\begin{array}{l}\text { - How satisfied are you with } \\
\text { the way your Supervisor helps you at } \\
\text { the time of need? }\end{array}$ & $\begin{array}{c}77 \\
(8.3)\end{array}$ & $\begin{array}{c}55 \\
(5.9)\end{array}$ & $\begin{array}{c}483 \\
(52.2)\end{array}$ & $\begin{array}{c}101 \\
(10.9)\end{array}$ & $\begin{array}{c}159 \\
(17.2)\end{array}$ & $\begin{array}{c}38 \\
(4.1)\end{array}$ & 4.0000 & 2.14354 \\
\hline $\begin{array}{l}\text { How satisfied are you with } \\
\text { how well your Supervisor answers } \\
\text { your questions? }\end{array}$ & $\begin{array}{c}80 \\
(8.6)\end{array}$ & $\begin{array}{c}176 \\
(19.0)\end{array}$ & $\begin{array}{c}412 \\
(44.5)\end{array}$ & $\begin{array}{c}143 \\
(15.4)\end{array}$ & $\begin{array}{c}52 \\
(5.6)\end{array}$ & $\begin{array}{c}41 \\
(4.4)\end{array}$ & 3.9736 & 2.55573 \\
\hline $\begin{array}{l}\text { What is your level of } \\
\text { satisfaction about how well your } \\
\text { Supervisor appreciates } \\
\text { contribution? }\end{array}$ & $\begin{array}{c}94 \\
(10.2)\end{array}$ & $\begin{array}{c}121 \\
(13.1)\end{array}$ & $\begin{array}{c}468 \\
(50.5)\end{array}$ & $\begin{array}{c}107 \\
(11.6)\end{array}$ & $\begin{array}{c}82 \\
(8.9)\end{array}$ & $\begin{array}{c}40 \\
(4.3)\end{array}$ & 3.9880 & 1.40369 \\
\hline $\begin{array}{l}\text { - How satisfied are you with how your } \\
\text { Supervisor addresses issues } \\
\text { surrounding your safety and work } \\
\text { environment? }\end{array}$ & $\begin{array}{c}89 \\
(9.6)\end{array}$ & $\begin{array}{c}166 \\
(17.9)\end{array}$ & $\begin{array}{c}476 \\
(51.4)\end{array}$ & $\begin{array}{c}70 \\
(7.6)\end{array}$ & $\begin{array}{c}76 \\
(8.2)\end{array}$ & $\begin{array}{c}33 \\
(3.6)\end{array}$ & 3.8855 & 1.3595 \\
\hline $\begin{array}{l}\text {-How satisfied are you with your } \\
\text { Supervisor's objective treatment of } \\
\text { official matters when it involves you } \\
\text { \& co-workers from the Supervisor's } \\
\text { ethnic tribe. }\end{array}$ & $\begin{array}{c}92 \\
(9.9)\end{array}$ & $\begin{array}{c}163 \\
(17.6)\end{array}$ & $\begin{array}{c}427 \\
(46.1)\end{array}$ & $\begin{array}{c}69 \\
(7.5)\end{array}$ & $\begin{array}{c}110 \\
(11.9)\end{array}$ & $\begin{array}{c}51 \\
(5.5)\end{array}$ & 3.8814 & 1.48047 \\
\hline
\end{tabular}




\begin{tabular}{|c|c|c|c|c|c|c|c|c|}
\hline Organizational Support Practices & $\begin{array}{c}\text { VS } \\
(\%)\end{array}$ & $\begin{array}{c}\mathbf{S} \\
(\%)\end{array}$ & $\begin{array}{c}\text { SS } \\
(\%)\end{array}$ & $\begin{array}{c}\text { SD } \\
(\%)\end{array}$ & $\begin{array}{c}\text { D } \\
(\%)\end{array}$ & $\begin{array}{l}\text { VD } \\
(\%)\end{array}$ & $\bar{X}$ & SD \\
\hline $\begin{array}{l}\text { Your Co-Workers } \\
\text { - What is your level of satisfaction on } \\
\text { how you and your co-workers help } \\
\text { each other get the job done? }\end{array}$ & $\begin{array}{c}98 \\
(10.6)\end{array}$ & $\begin{array}{c}367 \\
(39.6)\end{array}$ & $\begin{array}{c}178 \\
(19.2)\end{array}$ & $\begin{array}{c}110 \\
(11.9)\end{array}$ & $\begin{array}{c}115 \\
(12.4)\end{array}$ & $\begin{array}{c}43 \\
(4.6)\end{array}$ & 4.1427 & 2.45223 \\
\hline $\begin{array}{l}\text {-How satisfied are you with the } \\
\text { manner in which you and your co- } \\
\text { workers treat customers? }\end{array}$ & $\begin{array}{c}106 \\
(11.4)\end{array}$ & $\begin{array}{c}343 \\
(37.0)\end{array}$ & $\begin{array}{c}206 \\
(22.2)\end{array}$ & $\begin{array}{c}117 \\
(12.6)\end{array}$ & $\begin{array}{c}117 \\
(12.6)\end{array}$ & $\begin{array}{c}23 \\
(2.5)\end{array}$ & 4.1254 & 1.33175 \\
\hline $\begin{array}{l}\text { - How satisfied are you with the way } \\
\text { you \& your Co-workers communicate } \\
\text { with each other? }\end{array}$ & $\begin{array}{c}167 \\
(18.0)\end{array}$ & $\begin{array}{c}290 \\
(31.3)\end{array}$ & $\begin{array}{c}172 \\
(18.6)\end{array}$ & $\begin{array}{c}108 \\
(11.7)\end{array}$ & $\begin{array}{c}123 \\
(13.3)\end{array}$ & $\begin{array}{c}40 \\
(4.3)\end{array}$ & 4.1239 & 1.52872 \\
\hline $\begin{array}{l}\text { Senior Management: } \\
\text {-How satisfied are you with the way } \\
\text { the senior management understands } \\
\text { your stakeholders }\end{array}$ & $\begin{array}{c}45 \\
(4.9)\end{array}$ & $\begin{array}{c}337 \\
(36.4)\end{array}$ & $\begin{array}{c}205 \\
(22.1)\end{array}$ & $\begin{array}{c}150 \\
(16.2)\end{array}$ & $\begin{array}{c}117 \\
(12.6)\end{array}$ & $\begin{array}{c}43 \\
(4.6)\end{array}$ & 3.8399 & 1.38148 \\
\hline $\begin{array}{l}\text {-What is your level of satisfaction on } \\
\text { the way the Senior management } \\
\text { listens to employees? }\end{array}$ & $\begin{array}{c}32 \\
(3.5)\end{array}$ & $\begin{array}{c}116 \\
(12.5)\end{array}$ & $\begin{array}{c}464 \\
(50.2)\end{array}$ & $\begin{array}{c}118 \\
(2.7)\end{array}$ & $\begin{array}{c}150 \\
(16.2)\end{array}$ & $\begin{array}{c}31 \\
(3.3)\end{array}$ & 3.7784 & 1.29058 \\
\hline $\begin{array}{l}\text {-How satisfied are you with the way } \\
\text { the senior management works to } \\
\text { create a safe, rewarding environment? }\end{array}$ & $\begin{array}{c}115 \\
(12.4)\end{array}$ & $\begin{array}{c}309 \\
(33.4)\end{array}$ & $\begin{array}{c}263 \\
(28.4)\end{array}$ & $\begin{array}{c}113 \\
(12.2)\end{array}$ & $\begin{array}{c}35 \\
(3.8)\end{array}$ & $\begin{array}{c}28 \\
(3.0)\end{array}$ & 3.9017 & 1.30705 \\
\hline $\begin{array}{l}\text {-How satisfied are you with the level } \\
\text { of concern your organization shows to } \\
\text { you as a person? }\end{array}$ & $\begin{array}{c}124 \\
(13.4)\end{array}$ & $\begin{array}{c}115 \\
(12.4)\end{array}$ & $\begin{array}{c}482 \\
(52.1)\end{array}$ & $\begin{array}{c}87 \\
(9.4)\end{array}$ & $\begin{array}{c}65 \\
(12.4)\end{array}$ & $\begin{array}{c}38 \\
(7.0)\end{array}$ & 3.8779 & 1.46365 \\
\hline $\begin{array}{l}\text {-How satisfied are you with the } \\
\text { decisions your organization has made } \\
\text { in the past year? }\end{array}$ & $\begin{array}{c}44 \\
(4.8)\end{array}$ & $\begin{array}{c}84 \\
(9.1)\end{array}$ & $\begin{array}{c}24 \\
(2.6)\end{array}$ & $\begin{array}{c}154 \\
(16.6)\end{array}$ & $\begin{array}{c}559 \\
(60.4)\end{array}$ & $\begin{array}{c}48 \\
(5.2)\end{array}$ & 3.6020 & 1.36460 \\
\hline $\begin{array}{l}\text {-How satisfied are you with the } \\
\text { Mentoring and Coaching support you } \\
\text { are currently receiving from Senior } \\
\text { colleagues and Supervisors? }\end{array}$ & $\begin{array}{c}47 \\
(5.1)\end{array}$ & $\begin{array}{c}25 \\
(2.7)\end{array}$ & $\begin{array}{c}84 \\
(9.1)\end{array}$ & $\begin{array}{c}63 \\
(6.8)\end{array}$ & $\begin{array}{c}142 \\
(15.3)\end{array}$ & $\begin{array}{c}539 \\
(58.2)\end{array}$ & 3.4573 & 1.48554 \\
\hline $\begin{array}{l}\text { - How satisfied are you with the } \\
\text { Management's Support for your } \\
\text { efforts to improve your weaknesses to } \\
\text { enable you develop your Career? }\end{array}$ & $\begin{array}{c}30 \\
(3.2)\end{array}$ & $\begin{array}{c}100 \\
(10.8)\end{array}$ & $\begin{array}{c}50 \\
(5.4)\end{array}$ & $\begin{array}{c}168 \\
(18.1)\end{array}$ & $\begin{array}{c}83 \\
(8.9)\end{array}$ & $\begin{array}{c}480 \\
(51.8)\end{array}$ & 3.5442 & 1.32389 \\
\hline $\begin{array}{l}\text {-How satisfied are you with your } \\
\text { Supervisor's efforts to identify your } \\
\text { strengths and weaknesses and help } \\
\text { you work on improving them? }\end{array}$ & $\begin{array}{c}49 \\
(5.3)\end{array}$ & $\begin{array}{c}76 \\
(8.2)\end{array}$ & $\begin{array}{c}46 \\
(5.0)\end{array}$ & $\begin{array}{c}122 \\
(13.2)\end{array}$ & $\begin{array}{c}143 \\
(15.4)\end{array}$ & $\begin{array}{c}476 \\
(54.1)\end{array}$ & 3.6419 & 1.36568 \\
\hline $\begin{array}{l}\text {-How satisfied are you with the } \\
\text { quality of on-the-job - training } \\
\text { received for your current \& previous } \\
\text { positions in the NNPC }\end{array}$ & $\begin{array}{c}44 \\
(4.8)\end{array}$ & $\begin{array}{c}82 \\
(8.9)\end{array}$ & $\begin{array}{c}60 \\
(6.5)\end{array}$ & $\begin{array}{c}143 \\
(15.4)\end{array}$ & $\begin{array}{c}155 \\
(16.7)\end{array}$ & $\begin{array}{c}469 \\
(50.6)\end{array}$ & 3.6481 & 1.64829 \\
\hline
\end{tabular}

Note: $\bar{X}=$ mean, $\mathrm{VS}=$ Very Satisfied, $\mathrm{S}=$ Satisfied, $\mathrm{SS}=$ Slightly Satisfied, $\mathrm{SD}=$ Slightly Dissatisfied, $\mathrm{D}=$ Dissatisfied, VD = Very Dissatisfied

Source: Researcher's Field Survey Result, 2018

Table 2 presents the respondents' opinion on various issues of Organization Support practices (i.e. Supervisors, Co-workers, and Senior Management) by the Corporation. On the Organization Support practice with respect to Supervisors, the analysis indicates that 699 (75.4\%) of the respondents are not satisfied with how fairly their Supervisor treats them, 623(67.3\%) are not satisfied with their Supervisor's position when they have a problem with a co-worker in another department, 597(64\%) are not satisfied with the way their Supervisor helps them at the time of needs, $743(64.5 \%)$ are not satisfied with how well their Supervisor answers their questions, $607(65.5 \%)$ are not satisfied with the level at which their Supervisor appreciates their contribution, 657 (63.5\%) are not satisfied/happy with how their Supervisor addresses issues surrounding their safety and work environment, and $643(70.1 \%)$ are satisfied with their Supervisor's objective treatment of official matters when it involves them $\&$ co-workers from the Supervisor's ethnic tribe. On organization Support practice with respect to co-workers, the 
analysis revealed that $592(63.9 \%)$ indicate there is low level of satisfaction on how they and other co-workers help each other get the job done in the organization, $666(71.8 \%)$ are not satisfied with the manner in which they and their co-workers treat customers, and $570(61.1 \%)$ are not satisfied with the way they and Co-workers communicate with each other. Concerning Organization Support practice with Senior management, 692 (74.7\%) are not satisfied with the way the Senior management understands stakeholders, $732(74.5 \%)$ express low level of satisfaction and cooperation on the way the Senior management listens to employees, $685(77.7 \%)$ are not satisfied with the way the senior management works to create a safe, rewarding environment, $663(76.9 \%)$ are not satisfied with the level of concern their organization shows to them as a person, $501(54.6 \%)$ are slightly satisfied with the decisions the organization has made in the past years, $521(55.6 \%)$ are satisfied with the Mentoring and Coaching support they are currently receiving from Senior colleagues and Supervisors in the organization, 731 (78.8) are not satisfied with the Management's Support for their efforts to improve the weaknesses to enable them develop their Career, $741(82.7 \%)$ are not satisfied with the Supervisor's efforts to identify employees strengths and weaknesses and help them work on improving them, and $676(82.8 \%)$ are not satisfied with the quality of on-the-job - training received for their current and previous positions in the NNPC. Overall, majority of the respondents are not satisfied with the level of support they are receiving as it affects their Career Development (699 or 75.4\%).

The result in above the table shows apparently that Organization Support practice with respect to supervisors in NNPC is not encouraging. Supervisors hardly have time to helps employees at the time of needs, and there is high degree of mistrusts among Supervisors on critical issues. These problems adversely affected employee Career Development (See 1).

\subsection{Analysis of Personal Interview}

Question Four: (a) As a leader in the corporation, you are aware that the Corporation spends huge sum of money annually to undertake Learning and Development activities. What is your opinion regarding the value that the NNPC get as regarding Learning and Development Practices especially overseas Learning and Development opportunities?

(b) How would the NNPC improve the value creation from Learning and Development practices?

\subsection{Summary of Reponses:}

In NNPC, there is no effective Learning Management System in place to program each staff according to that career path needs because employees gain general knowledge and value from training programs. As long as Learning and Development are not related to Career development, it appears disjointed learning. Although acclaimed training and development is in place in NNPC; consultants are often not chosen based on expertise but as favours for friends and political associates. For overseas training, they are not given to employees for filling of skills gap but rather mainly for Estacode. Most staff regards overseas training as jamboree rather than opportunity for learning and development. Overseas training is often seen as a way to help friends in need. In addition, employees are not allowed to implement the outcome of training (e.g. the Chief Officers management program). NNPC do not ask for feedback from employees in order to measure the value of implementing training. There is no effective strategy for measuring the value of training. There is nothing on ground to evaluate and assess the impact of training. There is no measuring training template to harness the values of training. Generally, the value of training is not commensurate with the sum expended on training. The corporation does not get the expected value for expending such huge sum because there is no structure for skill gap identification and adequate interventions to fill the gap. Hence, the value that is derived from L\&D is very low when compared to the amount of money spent.

In order to improve L\& D in NNPC, there is need to develop and enhance in-depth industry culture to compete effectively. Also, there is the need to align the employee career goals with strategic goals for training purposes. For example, there is need to develop of a matrix of measuring the value addition as a result of such training. Training should be work based and align to improve performance. In addition, there should be consistent efforts to change the mind-set of employees that training is not all about touring Advance and Estacode but for Job improvement and Organizational performance. There should be a system to measure the effectiveness of all learning interventions.

To improve value creation, there has to be a review of the HR policy and processes, Structured Career path for each staff and skill gaps identified for each. There is need to align the program with identified gaps and strategic direction. Training must be aligning to strategic needs of the corporation and ensuring that they are well reviewed and implemented. The level of value addition should be used to determine the next year's budget for training.

\subsection{Test of Hypothesis}

A univariate analysis was used to empirically test the hypothesis formulated for this study. The hypothesis was tested at $95 \%$ level of confidence as a statistical basis for drawing conclusion. The responses for each variable were combined to generate composite scores which were used in the regression analysis. Organization Support 
practice was regressed on employee Career Development as shown in Table 3.

Table 3: Regression Results for the Influence of Organizational Support on Employee Career Development

\begin{tabular}{|l|c|c|c|c|c|}
\hline & \multicolumn{2}{|c|}{ Unstandardized Coefficients } & Standardized Coefficients & & \\
\cline { 2 - 6 } & B & Std error & Beta & t & Sig. \\
\hline Constants & 7.154 & 1.023 & & 6.996 & .000 \\
\hline Organizational Support & .328 & .213 & .555 & 2.210 & .867 \\
\hline $\mathrm{R}=0.555 \quad \mathrm{R}^{2}=0.308$ \\
Durbin Watson $=1.773$
\end{tabular}

a. Dependent variable: Employee Career Development

Source: Researcher's Field Survey from SPSS output, 2018

The regression model estimated in Table 3 for the influence of Organizational Support on Employee Career Development is presented below:

\section{Employees' career development $=7.154+0.328$ Organizational support practices}

Table 3 shows the regression analysis of Organizational Support practices and employees' career development. The result in the table indicated that Organizational Support practices has positive but non-significant effect on employee career development in NNPC $(\beta=.328, \mathrm{t}=2.210, \mathrm{p}>0.05)$. The Table shows that Organizational Support practices have no significant effect on employee career development $(F=3.146, p>0.05)$. Further, the Table shows that Organizational Support practices only contribute $30.8 \%$ variance in employees' career development. Based on this result, the null hypothesis $\left(\mathrm{H}_{0}\right)$ which states that Organizational Support practices do not significantly influence employees' career development is hereby accepted.

\subsection{Discussion}

The findings of this study revealed that Organizational Support practices do not significantly influence employees' career development. This implies that there is no significant relationship between Organizational Support practices and employees' career development in NNPC. The results are consistent with data in Table 4.8. From Table 4.8 $67.3 \%$ of the respondents are not satisfied with their Supervisor's position when they have a problem with a coworker in another department. Also, 64.5\% are not satisfied with how well their Supervisor answers their questions. Further, 70.1\% of the respondents are no satisfied with their Supervisor's objective treatment of official matters when it involves them \& co-workers from the Supervisor's ethnic tribe. Based on these findings, the study accepts the null hypothesis $\left(\mathrm{H}_{0}\right)$ which states that Organizational Support practices do not significantly influence employees' career development.

\section{Conclusion and Recommendations}

Human Resources Management (HRM) practices in any organization is critical to the achievement of the organization's objective. This study investigated the influence Organizational Support practices on employees' career development in NNPC. On the basis of the findings, the researcher inferred some important conclusions:

In regard to the descriptive statistics about career development, there is no established career path for every employee and professional groups in NNPC; and training and development opportunities are not explicitly linked to the Career direction of the employees nor directly linked to the strategic direction of NNPC. As a result, employees do not really know the key skills that Corporation needs to achieve its objectives.

In addition, employees in NNPC do not receive formal Career advice from their Supervisors and Managers. Similarly, Organization Support practice with respect to supervisors in NNPC is not encouraging. Supervisors hardly have time to helps employees at the time of needs, and there is high degree of mistrusts among Supervisors on critical issues. These problems adversely affected employee Career Development. Furthermore, Organizational Support practices is not statistically significant and therefore Organizational Support practices do not significantly influence employees' career development.

The study recommended that NNPC should adopt an integrated approach toward formulation and implementation of HRM practices. This will provide a holistic approach to the implementation of HRM practices, guidelines and procedures in the Corporation and it's Strategic Business Units (SBUs). This study provides factors that will be used to identify instantly the HRM practices that actually contribute to the employee career development in the corporation. Also, External political interference should be reduced to the barest minimum. The Organization must be allowed to run as a growing concern and the leadership held accountable for all their actions.

This study sought to investigate the influence of Organizational Support practices on employee career development in NNPC. In this cases, the findings and conclusion are limited to NNPC. Future research should focus on validating the findings and conclusion of the study by undertaking replicative researches in specific areas of the Oil and Gas Industry like Downstream and Upstream sectors in Nigeria. 


\section{References}

Agba, A. M. O., Nkpoyen, F., \& Ushie, E. M. (2010). Career development and employee commitment in industrial organisations in Calabar, Nigeria. American Journal of Scientific and Industrial Research, 1(2), 105-114

Akgunduz, Y., Alkan, C. \& Gok, O.A. (2018), Perceived Organizational Support, Employee Creativity and Proactive Personality: The Mediating Effect of Meaning of Work. Journal of Hospitality and Tourism Management 34 pp105-114

Atkinson, C. (2002). Career Management and the Changing Psychological Contract... Career Development International, 7(1), 14-23

Barnett, B. R., \& Bradley, L. M. (2007). The Impact of Organisational Support for Career Development on Career Satisfaction. Career Development International, 12(7), 617-636.

Bayram, C. (2008). Career Planning and Its Management (Baskı).İstanbul: Kumsaati Yayın Dağıtım Ltd.Şti.

Bish, A. J., Bradley, L. M., \& Sargent, L. D. (2004). Career Development For Going Beyond The Call Of Duty: Is It Perceived As Fair? Career Development International, 9(4), 391-405.

Briscoe, J.P., Hall, D. T., \& Demuth, R.L.F. (2006). Protean and Boundaryless Careers: An Empirical Exploration. Journal of Vocational Behavior, 69, 4-18

Bryman, A. \& Bell, E. (2011). Business Research Methods, 4th Ed. Oxford-UK: Oxford University Press. UK

Crawshaw, J. R. \& Gameb, A. (2015). The Role of Line Managers in Employee Career Management: An attachment Theory Perspective. The International Journal of Human Resource Management. Routledge Taylor \& Francis Group, 26(5)

Cropanzano, R., Howes, J. C., Grandy, A.A., \& Toth, P. (1997). The Relationship of Organizational Politics and Support to Work Behaviours, Attitudes, and Stress. Journal of Organizational Behavior. 22, 159-180

David, F.A, (2009), Statistical models: Theory and Practice (revised ed) UK Cambridge University Press.

Danesi, R. A. (2008). The Changing Nature of Work: Causes of and Effects on Employment Relationships in Nigeria; paper Presented at the International Labour Organization Conference in Johannesburg, South Africa. http://www.ilera2015.com/dynamic/full/IL92.pdf: Accessed March 15, 2016

Demir, K. (2015). The effect of organizational justice and perceived organizational support on organizational citizenship behaviors: The mediating role of organizational identification. Eurasian Journal of Educational Research, .60. (8)

Dawis, R.V., England, G.W., \& Lofquist, L.H. A. (1964). A theory of work Adjustment. Minnesota Studies in Vocational Rehabilitation. XV

Dawis, R. V, (1992). The Individual Difference Tradition in Counselling Psychology. Journal of Counselling Psychology, 39.7-19

Dawis, R. V. \& Lofquist, L.H. (1984). A Psychological Theory of Work Adjustment. Journal of Vocational Behavior, 2(3)

Dawis, R. V. (2002). Person -Environment-Correspondence theory, In D. Brown and Associates (eds.) Career Choice and Development, (4th Edition 427-464), San Francisco, CA Jossy Bass.

Dawis, R. V. (2005). The Minnesota Theory of Work adjustment. In S. D. Brown \& R. W. Lent (Eds.), Career Development and Counselling: Putting Theory and Research to work, 3-23. Hoboken, NJ: John Wiley.

Eder, P \& Eisenberger, R (2008).Perceived Organizational Support: Reducing the Negative Influence of Coworker Withdrawal Behavior; Journal of Management 34(55)

Eggerth, D. E. (2008). From Theory of Work Adjustment to Person-Environment Correspondence Counselling: Vocational Psychology as Positive Psychology. Journal of Career Assessment, SAGE Journals Publications, 16(1), 60-74

Eisenberger, R., Stinglhamber, F, F., Vandenberghe, C., Sucharski, I.L., \& Rhoades, L. (2002). Perceived Supervisor Support: Contribution to Perceived Organizational Support and Employee Retention. Journal of Applied Psychology, 87(3), 565-573

Eisenberger, R., Rhoades, L. \& Cameron, J. (1999). Does pay for performance increase or decrease perceived Selfdetermination and intrinsic motivation? Journal of Personality and Social Psychology, 77(5) 1026-1040

Fapohunda, T.M. (2012). Employment Casualization and Degradation of Work in Nigeria. International Journal of Business and Social Sciences, 3(9)

Gilbert, L .L. (2014. Leading Organizational Change Management in Nigerian Oil Organisations: A study of the NNPC Transformation and Change Projects. A Ph.D. Thesis Submitted to the University of South Wales, UK

Gilbert. L. L. Djebarni, R.; \& Thomas, B.C. (2015). "Leading Organisational Change Management in Nigerian Oil Organisations: Exploring the Adoption of a Leadership and Competing Values Framework (CVF) Model", The International Journal of Knowledge, Culture \& Change Management, 14 (2).9-24

Greenberg, J. (1990). Organizational Justice: Yesterday, Today and Tomorrow. Journal of Management, 16, 399432.

Ikoh, M.U \& Ukpong, E. A. (2013). The Niger Delta Crises: Taming Violence Beyond the Amnesty. International Journal of Humanities and Social Science, 3(17), 146-159. 
Ikelegbu, A (2005). The Economy of Conflict in the Oil Rich Niger Delta Region of Nigeria, Nordic Journal of African Studies, 14(2), 208-234

Kerlinger, F. N., \& Lee, H. B. (2000). Foundations of behavioral research (4th ed.). Holt, NY: Harcourt College Publishers.

Kang, H. J., Gatling, A\& Kim, J. (2014). The Impact of Supervisory Support on Organizational Commitment, Career Satisfaction, and Turnover Intention for Hospitality Frontline Employees; Journal of Human Resources in Hospitality \& Tourism 14(1) Taylor-Francis online

Kaya, C \& Ceylan, B. (2014). An Empirical Study on the Role of Career Development Programs in Organization and Organizational Commitment on the Job Satisfaction of Employees. American Journal of Business and Management, 3(3), 178-191

Levinson, H. (1965). Reciprocal: The relationship between man and the Organization; Administrative Science Quarterly, 9. 370-390

Meiske, C (2018). The Influence of Perceived Organizational Support, job Satisfaction and Organizational Commitment towards Organizational citizen Behaviour (A study of the permanent Lecturersof University of Lamburg, Mangkurat, Banjarmasin) Journal of Indonesian Economy and Business 33(1) 23-45

Newsom, C. (2011). Conflict in the Niger Delta: More Than a Local Affair, United States Institute of Peace, Special Report, 271

Nwachukwu, C. \& Eboh, M (2015). Gale of Sacks Sweep through NNPC, Vanguard Newspapers vanguardngr.com August 6th 2015

Odhong, A, Were, S. \& Omolo, J. (2014). Effect Of Human Capital Management Drivers on Organizational Performance in Kenya: A Case of Investment and Mortgages Bank Ltd. European Journal of Business Management 2 (1), 341-356.

Orvis, K. A. \& Leffler, G. P. (2011). Individual and Contextual Factors: An Interactionist Approach to Understanding Employee Self-development. Journal of Personality \& Individual Differences, 51, 172-177

Randall, M. L. Cropanzano, R. Bormann, C.A. Birjulin, A (1999). Organizational politics and organizational support as predictors of work attitudes, job performance, and organizational citizenship behavior. Journal of $\begin{array}{lll}\text { Organizational } & \text { Behaviour } & \text { 20(2) }\end{array}$ citeseerx.ist.psu.edu/viewdoc/download?doi=10.1.1.466.4267\&rep=rep1\&type $=$ pdf Accessed May 2018

Rasool, S., Kiyani, A. A., Aslam, M. J. \& Akran, M. U. (2012). The Impact of Organizational Culture on Employee Career Salience: An Empirical Study of the Banking Sector in Islamabad, Pakistan. International Journal of Business and Social Science, 3(7)

Rhoades, L \& Eisenberger, R. (2002). Perceived Organizational Support: A Review of the Literature; Journal of Applied Psychology 87(4) 698-714

Saeed, R.; Lodhi, R. N.; Abbas, F; Ishfaque, U; Dustgeer, F \& Ahmed, M. (2013). The Organizational Role in Career Development of Employees; Management and Administrative Science Review. Academy of Business and Scientific Research. 2(6), 664-669.

Saleem, S, Amin, S (2013). The Impact of Organizational Support for Career Development and Supervisory on Employee Performance: An Empirical Study from Pakistani academic Sector. European Journal of Business \& Management, 5(5)

Sayne, A, Gillies, A \& Katsouris (2015). Inside NNPC Oil Sales: A Case For Reform in Nigeria. Natural Resources Governance Institute

Schein, E. H (1990). Career Anchors and Job/Role Planning: The Links between Career Patting and Career Development. American Psychologists Association, 45(2), 108-119

Shah, M. A. Mallah, M \& Shabana, M. (2015). Impact of Human Resources Practices on Employee Retention: Study of Community Colleges. Case Studies Journal, 4(8)

Sharjeel, Saleem \& Amin, S. (2013). The Impact of Organizational Support for Career Development and Supervisory Support on Employee Performance: An Empirical Study of Pakistan Academic Sector. European Journal of Business and Management; 5(5) 2222-2839

Shore, L. M., \& Shore, T. H. (1995). Perceived Organizational Support and Organizational Justice. Organizational Politics, Justice, and Support: Managing the Social Climate of the Workplace, 149-164.

Shujaat, S, Sana S, Aftab, F, \& Ahmed, I (2013). Impact of Career Development on Employee Satisfaction in Private Banking Sector in Karachi. Journal of Management and Social Sciences, 9(2)

Suleiman, A (2011). Nigeria: NNPC, National Assembly and the Economy, Leadership Newspaper, Abuja, Nigeria

Wayne, S. J., Shore, L. M. Bommer, W. H, \& Tetrick, L. E. (2002). The Role of Fair Treatment and Rewards in Perceptions of Organizational Support and Leader- Member Exchange. Journal of Applied Psychology. 87 (3) $590-598$

Wayne, S.J., Shore, L.M., \& Laden, R.C. (1997). Perceived Organizational Support and Leader-Member Exchange: A Social Exchange Perspective. Academy of Management Journal, 40, 82-111. 
Wen, P \& Said in, K.B (2018). A study of the Relationship between Perceived Organizational Support and Work Engagement of Administrative staff in a Newly established University in China, Journal of Social Sciences Research ,12(2)

$\mathrm{Wu}$, Chao-Chan \& Liu, Na-Ting (2014). Perceived Organizational Support, Organizational Commitment and Service-Oriented Organizational Citizenship Behaviours. International Journal of Business and Information. 9 (1).

Yarmall, J. (1998). Line Managers as Career Developers: Rhetoric or Reality? Personnel Review, Emerald Insight, 27(5), 378-395 